\title{
Contribution of polymorphonuclear neutrophils in the blood periphery to ischemic brain injury
}

Dirk M. Hermann, MD, and Matthias Gunzer, PhD

Neurol Neuroimmunol Neuroinflamm 2019;6:e570. doi:10.1212/NXI.0000000000000570

Three major lines of argumentation presently support a role of polymorphonuclear neutrophils (PMNs) in ischemic brain injury:

1. PMNs abundantly accumulate in ischemic brain tissue in response to stroke both in rodents and human patients, where they massively release enzymes, such as myeloperoxidase and elastase, and reactive oxygen species (ROS), which are known contributors to ischemic injury. $^{1-3}$

2. In mouse models of ischemic stroke induced by intraluminal middle cerebral artery occlusion (MCAO), the selective depletion of PMNs by anti-Ly6G antibody or prevention of PMN brain entry by CXCR2 or VLA-4 blockade significantly reduces ischemic injury and neurologic deficits. ${ }^{4,5}$

3. In patients with ischemic stroke, high neutrophil counts or high neutrophil to lymphocyte ratios in the blood on admission are associated with poor neurologic outcome even when adjustments for age, sex, vascular risk factors, and stroke severity are made.,

The combined evidence of these studies has prompted the idea that blood-derived PMNs are attracted into the ischemic brain, where they aggravate brain injury. ${ }^{8}$

In this issue of Neurology: Neuroimmunology \& Neuroinflammation, Weisenburger-Lile et al. ${ }^{9}$ further strengthened and expanded this view, providing a detailed and comprehensive analysis of peripheral blood PMN characteristics in a cohort of 41 patients with acute ischemic stroke, which were compared with 22 healthy control subjects of the same age who were close relatives of patients. Blood samples were collected within 6 hours after stroke onset and, in a subgroup of patients, after 2 and 7 days. Flow cytometry studies revealed hyperactivation of circulating PMNs in the acute stroke phase, that is, within 6 hours after stroke, indicated by decreased CD62L and increased CD11b expression on PMNs, increased ROS production by unstimulated and stimulated PMNs, and increased circulating elastase levels in peripheral blood. The number of necrotic PMNs was increased from 2 to 7 days after stroke, whereas the concentration of neutrophil extracellular trap components in the serum was decreased. An increased percentage of senescent, that is, CXCR4 $4^{\text {bright }} / \mathrm{CD} 62 \mathrm{~L}^{\text {dim }} \mathrm{PMN}$ was noted at all 3 time points examined. PMNs with the capacity to reversely transmigrate from inflamed tissues back into the blood, defined as $\mathrm{CD} 54^{\text {high }} / \mathrm{CXCR} 1^{\text {low }}$, were increased in patients with stroke. States of hyperactivation, senescence, and reverse migration were particularly pronounced in PMNs from patients exhibiting a high NIH Stroke Scale score $(>12)$ on admission. The authors hypothesize that changes in PMN homeostasis may instrumentally contribute to ischemic brain injury, e.g., by promoting systemic inflammation, promoting blood-brain barrier breakdown, or inducing immunomodulation. The authors suggest that rebalancing PMN subsets or preventing reverse PMN transmigration might alleviate stroke consequences.

\author{
Correspondence \\ Dr. Hermann \\ dirk.hermann@uk-essen.de \\ or Dr. Gunzer \\ matthias.gunzer@uk-essen.de
}

\section{RELATED ARTICLE}

Harmful neutrophil subsets in patients with ischemic stroke: Association with disease severity

Page e571

From the Department of Neurology (D.M.H.), University Hospital Essen, University of Duisburg-Essen; and Institute of Experimental Immunology and Imaging (M.G.), University Hospital Essen, University of Duisburg-Essen, Germany.

Go to Neurology.org/NN for full disclosures. Funding information is provided at the end of the article.

This is an open access article distributed under the terms of the Creative Commons Attribution-NonCommercial-NoDerivatives License 4.0 (CC BY-NC-ND), which permits downloading and sharing the work provided it is properly cited. The work cannot be changed in any way or used commercially without permission from the journal. 
The clear strength of this study is a meticulously conducted characterization of PMN subsets that provides a first in-depth characterization of PMN changes in ischemic stroke. A downside is the choice of control subjects, which, representing healthy humans, do not exhibit a similar vascular risk profile. Differences in vascular risk factors and associated diseases (coronary heart disease and large artery atherosclerosis) may at least partly account for the observations made. Hence, confirmation studies in an independent patient cohort matched for risk factors and comorbidities will be required. Also, functional readouts of PMN activity such as migration should be studied in more detail, ${ }^{10}$ as they are further indicators of disease states.

What can we learn from these studies? In the past, we have perhaps focused too exclusively on the PMN-associated aggravation of ischemic injury inside the brain. By modulating immune responses in peripheral blood, reversely transmigrated PMNs might potentially deregulate the neurovascular unit or exert bystander effects on additional immune cells such as $\mathrm{T}$ cells in the blood, which on brain entry may aggravate ischemic damage. ${ }^{11}$ In line with this hypothesis, we have previously shown after intraluminal MCAO in mice that the delivery of antibodies inhibiting the integrin VLA-4, which mediates the entry of $\mathrm{T}$ cells and PMNs into the brain, did not show any additional protective effects when PMNs had been depleted. ${ }^{4}$ The depletion of PMNs alone provided maximum protection. However, antiVLA-4 acted synergistically with a selective T cell-depleting antibody to provide maximum protection. ${ }^{4}$ Hence, in this model, PMNs appeared to be a master switch that was responsible for the injury-promoting capacity of both PMNs and $\mathrm{T}$ cells. The combined evidence of the now presented study and our earlier study suggests that PMNs might act as an amplifier of detrimental immune responses that compromise stroke outcome. Further studies on this issue are warranted.

\section{Study funding}

Supported by Deutsche Forschungsgemeinschaft (HE3173/ 11-1, GU769/10-1).

\section{Disclosure}

D. Hermann has served on the scientific advisory board of Servier; has served on the editorial boards of Frontiers of Cellular Neurosciences and Basic Research in Cardiology; and has received research support from the German Research Foundation. M. Gunzer has received speaker honoraria from Hexal and Mundipharma. Go to Neurology.org/NN for full disclosures.

\section{References}

1. Gelderblom M, Leypoldt F, Steinbach K, et al. Temporal and spatial dynamics of cerebral immune cell accumulation in stroke. Stroke 2009;40:1849-1857.

2. Liesz A, Zhou W, Mracskó É, et al. Inhibition of lymphocyte trafficking shields the brain against deleterious neuroinflammation after stroke. Brain 2011;134: 704-720.

3. Perez-de-Puig I, Miro-Mur F, Ferrer-Ferrer M, et al.. Neutrophil recruitment to the brain in mouse and human ischemic stroke. Acta Neuropathol 2015;129: 239-257.

4. Neumann J, Riek-Burchardt M, Herz J, et al. Very-late-antigen-4 (VLA-4)-mediated brain invasion by neutrophils leads to interactions with microglia, increased ischemic injury and impaired behavior in experimental stroke. Acta Neuropathol 2015;129:259-277.

5. Herz J, Sabellek P, Lane TE, Gunzer M, Hermann DM, Doeppner TR. Role of neutrophils in exacerbation of brain injury after focal cerebral ischemia in hyperlipidemic mice. Stroke 2015;46:2916-2925.

6. Maestrini I, Strbian D, Gautier S, et al. Higher neutrophil counts before thrombolysis for cerebral ischemia predict worse outcomes. Neurology 2015;85:1408-1416.

7. Xue J, Huang W, Chen X, et al. Neutrophil-to-lymphocyte ratio is a prognostic marker in acute ischemic stroke. J Stroke Cerebrovasc Dis 2017;26:650-657.

8. Hermann DM, Gunzer M. Polymorphonuclear neutrophils play a decisive role for brain injury and neurological recovery poststroke. Stroke 2019;50:e40-e41.

9. Weisenburger-Lile D, Dong Y, Yger M, et al. Harmful neutrophil subsets in patients with ischemic stroke: Association with disease severity. Neurol Neuroimmunol Neuroinflamm 2019;6:e571. doi: 10.1212/NXI.0000000000000571.

10. Schuster M, Moeller M, Bornemann L, et al. Surveillance of myelodysplastic syndrome via migration analyses of blood neutrophils: a potential prognostic tool. J Immunol 2018;201:3546-3557.

11. de Oliveira S, Rosowski EE, Huttenlocher A. Neutrophil migration in infection and wound repair: going forward in reverse. Nat Rev Immunol 2016;16:378-391. 


\section{Neurology \\ Neuroimmunology \& Neuroinflammation}

\section{Contribution of polymorphonuclear neutrophils in the blood periphery to ischemic brain injury}

Dirk M. Hermann and Matthias Gunzer

Neurol Neuroimmunol Neuroinflamm 2019;6;

DOI 10.1212/NXI.0000000000000570

This information is current as of May 15, 2019

\section{Updated Information \& \\ Services}

References

Subspecialty Collections

Permissions \& Licensing

Reprints including high resolution figures, can be found at:

http://nn.neurology.org/content/6/4/e570.full.html

This article cites 11 articles, 3 of which you can access for free at: http://nn.neurology.org/content/6/4/e570.full.html\#\#ref-list-1

This article, along with others on similar topics, appears in the following collection(s):

All Immunology

http://nn.neurology.org//cgi/collection/all_immunology

Infarction

http://nn.neurology.org//cgi/collection/infarction

Information about reproducing this article in parts (figures,tables) or in its entirety can be found online at:

http://nn.neurology.org/misc/about.xhtml\#permissions

Information about ordering reprints can be found online:

http://nn.neurology.org/misc/addir.xhtml\#reprintsus

Neurol Neuroimmunol Neuroinflamm is an official journal of the American Academy of Neurology.

Published since April 2014, it is an open-access, online-only, continuous publication journal. Copyright

Copyright $\odot 2019$ The Author(s). Published by Wolters Kluwer Health, Inc. on behalf of the American

Academy of Neurology.. All rights reserved. Online ISSN: 2332-7812.

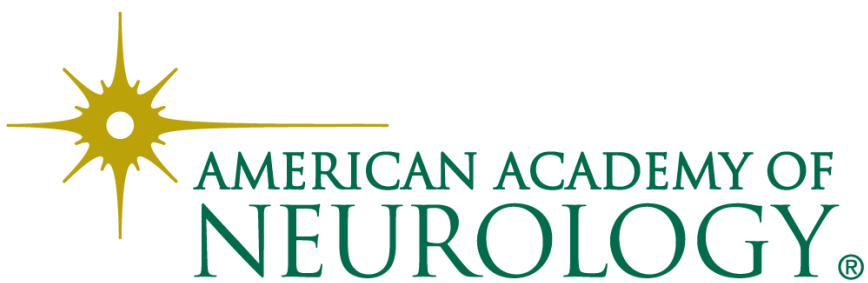

